\title{
OPPORTUNISTIC INFECTIONS IN PATIENTS WITH AIDS ADMITTED TO AN UNIVERSITY HOSPITAL OF THE SOUTHEAST OF BRAZIL
}

\author{
Vandack NOBRE(1), Emanuella BRAGA(1), Abdunnabi RAYES(1), José Carlos SERUFO(1), Pérsio GODOY(2), Nívea NUNES(1),
}

Carlos Maurício ANTUNES(3) \& José Roberto LAMBERTUCCI(1)

\begin{abstract}
SUMMARY
Opportunistic diseases in HIV-infected patients have changed since the introduction of highly active anti-retroviral therapy (HAART). This study aims at evaluating the frequency of associated diseases in patients with AIDS admitted to an university hospital of Brazil, before and after HAART. The medical records of 342 HIV-infected patients were reviewed and divided into two groups: group 1 comprised 247 patients before HAART and, group 2, 95 patients after HAART. The male-to-female rate dropped from 5:1 to 2:1 for HIV infection. There was an increase in the prevalence of tuberculosis and toxoplasmosis, with a decrease in Kaposi's sarcoma, histoplasmosis and cryptococcosis. A reduction of in-hospital mortality (42.0\% vs. $16.9 \% ; \mathrm{p}=0.00002)$ has also occurred. An agreement between the main clinical diagnoses and autopsy findings was observed in 10 out of 20 cases (50\%). Two patients with disseminated schistosomiasis and 2 with paracoccidioidomycosis are reported. Overall, except for cerebral toxoplasmosis, it has been noticed a smaller proportion of opportunistic conditions related to severe immunosuppression in the post HAART group. There was also a significant reduction in the in-hospital mortality, possibly reflecting improvement in the treatment of the HIV infection.
\end{abstract}

KEYWORDS: HIV; AIDS; Opportunistic diseases; Schistosomiasis; Paracoccidioidomycosis.

\section{INTRODUCTION}

We now know that untreated human immunodeficiency virus (HIV) disease often progresses in most infected persons from clinically silent infection detectable only by laboratory tests to severe immunologic dysfunction, resulting in the acquired immunodeficiency syndrome (AIDS).

Untreated patients with manifestations of advanced HIV disease frequently have CD4+ lymphocytes counts below 200 cells $/ \mathrm{mm}^{3}$, increased plasma HIV RNA levels, and clinical manifestations indicative of severe immunocompromise, including conditions qualifying as CDCdefined $\mathrm{AIDS}^{4}$. In this scenario, thence, opportunistic infection is common.

Striking subjective and objective clinical improvement occurs in patients with significant symptomatic HIV disease, including many with AIDS and CD4+ counts below 100 cells $/ \mathrm{mm}^{3}$, who begin an appropriate HAART (highly active antiretroviral therapy) regimen, adhere successfully to it, and do not experience significant adverse medication effects.

The concept of AIDS as end-stage immunodeficiency is somewhat clouded by the recent advances in antiretroviral therapy, which may produce improvement in immunologic function, in AIDS-defining criteria (such as CD4+ count below 200 cells $/ \mathrm{mm}^{3}$ ), and in the incidence of opportunistic infections ${ }^{15,17,22,23,28}$.

The relative frequencies of specific opportunistic diseases may vary in different countries and even in different areas within the same country ${ }^{8,16}$. We conducted this retrospective study to determine the spectrum of opportunistic infections and malignancies in hospitalized patients, before and after the introduction of the HAART regimen, in a General University Hospital of Belo Horizonte, state of Minas Gerais, in Brazil.

\section{MATERIAL AND METHODS}

Patients: We reviewed the medical records of 342 HIV-infected patients seen from February 1989 to December 2000 at the General Hospital of the Federal University of Minas Gerais, in Brazil. Patients were divided into two groups: group 1 (247 patients) admitted to hospital from 1989 to 1996 and group 2 (95 patients) admitted after December 1996. The patients were referred to us because they presented symptoms presumed to be due to HIV infection or were admitted to hospital to investigate signs or symptoms of unknown origin, such as prolonged fever ${ }^{14}$. A standardized questionnaire was filled out for each and every patient containing epidemiological data, the presenting clinical profile and all tests contributing to a diagnosis. 


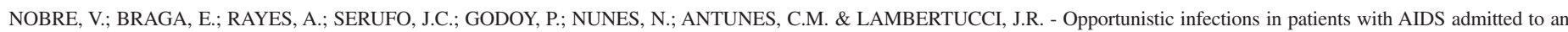
university hospital of the southeast of Brazil. Rev. Inst. Med. trop. S. Paulo, 45(2):69-74, 2003.

Diagnosis of opportunistic diseases: The diagnosis of Pneumocystis carinii pneumonia was accepted in patients who responded to treatment with trimethoprim-sulfametoxazole, and had a convincing clinical picture and radiological findings. One patient from each group had the agent identified in the bronchoalveolar lavage. The diagnosis of tuberculosis was based on the identification of the agent in tissues or sputum (ZiehlNielsen staining, and culture were routinely performed when tuberculosis was suspected); also, a complete response of symptoms to treatment with rifampin, isoniazid and pyrazinamide and suggestive histological findings in biopsy specimens were considered diagnostic. The diagnosis of Mycobacterium avium complex (MAC) was admitted when acid fast bacilli were recovered from tissues or blood, the symptoms were consistent with MAC infection, the CD4+ T-lymphocytes count was below 100, and a good clinical response was obtained with clarithromycin associated with ethambutol.

Toxoplasmic encephalitis was diagnosed when a patient with a convincing clinical picture had abnormal and suggestive computed tomographic scan or magnetic resonance imaging of the brain. A satisfactory response to antitoxoplasma therapies and positive serum IgG antibody to Toxoplasma gondii were also required. Brain biopsies were performed in cases which the standard treatment for toxoplasmosis failed. Cryptococcal meningitis was diagnosed when there was evidence of neurological involvement and a lumbar puncture revealed positive China ink preparation for fungi. The other opportunistic diseases were diagnosed according to criteria suggested by $\mathrm{CDC}^{4}$.

Autopsy: 17 individuals (3.9\%) from group 1 and 3 (3.2\%) from group 2 were submitted to autopsy (non-probabilistic sample) following the protocol of the Department of Pathology of the Faculty of Medicine, Federal University of Minas Gerais, Brazil.

HIV serology: All samples were tested by an enzyme-linked immunosorbent assay (Abbot Laboratories, California-USA). Positive samples were retested by ELISA and subsequently by Western blot (Sanofi Diagnostics, Pasteur Inc., France). A Western blot was judged to be positive if both core and envelope bands (p24 and gp120/160 or gp41) were present (CDC/ASTPHLD criteria).

The treatment of AIDS: The treatment of AIDS before 1996 was mostly performed using single agents like zidovudine (ZDV). Highly active antiretroviral therapy (HAART) was considered in the present study a regimen containing a protease inhibitor and two older nucleoside analogues, such as zidovudine (ZDV) and lamivudine (3TC).

Statistical analysis: The information obtained was stored in a computer data bank using the Epi Info version 6 software. The chisquared and $t$ (Student) tests were respectively used to analyze differences in proportions and means.

\section{RESULTS}

Profile of the patients: There was no significant difference of age distribution and CD4+ cell counts between the two groups (Table 1). 206 out of 247 (83.4\%) group 1 patients and 64 out of 95 (67.4\%) group 2 patients were male (male-to-female ratio of 5:1 and 2:1, respectively). The proportion of sexual transmission was high in both groups (99 out of $131 ; 75.6 \%$ in group 1 and 51 out of $61 ; 83.6 \%$ in group 2 ), but there
Table 1

Baseline characteristics of patients with AIDS admitted to a General University Hospital in Brazil in the period of February 1989 to December 2000. Group 1 = patients admitted to hospital before HAART was available; Group 2 = after HAART became available

\begin{tabular}{lcc}
\hline Characteristics & \multicolumn{2}{c}{ No. of Patients $(\%)$} \\
\cline { 2 - 3 } & Group 1 & Group 2 \\
\hline Age in years (mean \pm standard deviation) & $37.4 \pm 11.2$ & $35.0 \pm 10.8$ \\
$15-19$ & $7(2.8)$ & $3(3.2)$ \\
$20-39$ & $150(60.7)$ & $65(68.4)$ \\
$40-59$ & $79(32.0)$ & $23(24.2)$ \\
$>60$ & $11(4.5)$ & $4(4.2)$ \\
\hline Mode of transmission of HIV & & \\
Homosexual & $54(21.8)$ & $15(15.7)$ \\
Heterosexual & $29(11.7)$ & $33(34.7)$ \\
Bisexual & $16(6.4)$ & $3(3.1)$ \\
Transfusion of blood or & $18(13.7)$ & $2(2.1)$ \\
blood derivatives & & \\
IDUs & $13(7.2)$ & $7(7.3)$ \\
Occupational exposure & $1(0.4)$ & $1(1.0)$ \\
Unknown & $116(46.9)$ & $34(35.7)$ \\
Total & $247(100)$ & $95(100)$ \\
\hline CD4+ lymphocyte count/ $\mu \mathrm{L}$ & $131.1 \pm 164.3$ & $124.4 \pm 152.0$ \\
(mean \pm standard deviation) & & \\
$<100$ & $57(61.3)$ & $42(60.8)$ \\
$100-199$ & $17(18.3)$ & $14(20.3)$ \\
200-299 & $9(9.7)$ & $6(8.7)$ \\
300-399 & $3(3.2)$ & $3(4.3)$ \\
$400-499$ & $2(2.2)$ & $1(1.4)$ \\
$>500$ & $5(5.4)$ & $3(4.3)$ \\
Total & $93(100)$ & $69(100)$ \\
\hline
\end{tabular}

HAART = highly active anti-retroviral therapy; ${ }^{\text {a }}$ injecting drug users; refusals and not stated removed from table

was a higher participation of heterosexual practice as risk factor in group 2 patients $(22.1 \%$ vs. $54.1 \%)$ (Table 1$)$. The time spent in hospital was different between the two groups (mean of 19.2 and 32.7 days, respectively for groups 1 and $2 ; \mathrm{p}=0.001) .104$ patients $(42 \%)$ in group 1 and 16 patients $(16.9 \%)$ in group 2 died during hospitalization $(\mathrm{p}=$ 0.00002 ).

Opportunistic infections: The signs and symptoms which brought patients to hospital in search for help and clinical investigation varied. The main organs affected at admission were not different among the groups: the respiratory system, central nervous system, digestive system and blood elements.

The frequency of opportunistic infections among the 342 patients is shown in Table 2. 460 diagnoses were described in group 1 patients (mean: 1.9 per patient; range: 1 to 6 ) and 272 in group 2 (mean 2.9 per patient; range: 1 to 6 ). The most common opportunistic conditions were similar, but there was a drop of Kaposi's sarcoma (23 vs. 3 patients; $\mathrm{p}=$ $0.08)$, meningeal cryptococcosis (16 vs. $5 ; \mathrm{p}=0.86)$ and histoplasmosis ( 4 vs. 0 patients; $\mathrm{p}=0.270$ ) prevalence in group 2 when compared to group 1. Also, an increase in the occurrence of tuberculosis ( 23 vs. 25 
Table 2

Prevalence of the main opportunistic infections and malignancies in 342 HIV-infected patients seen at the General Hospital of the Federal University of Minas Gerais, in Brazil, from February 1989 to December 2000. Group 1 = patients admitted to hospital before HAART was available; Group 2 = after HAART became available

\begin{tabular}{|c|c|c|c|}
\hline \multirow[t]{2}{*}{ Condition } & \multicolumn{3}{|c|}{ No. $(\%)$ of patients } \\
\hline & Group 1 & Group 2 & $(\mathrm{p}<0.05)$ \\
\hline \multicolumn{4}{|l|}{ Opportunistic infections } \\
\hline Candidiasis ${ }^{\mathrm{a}}$ & $108(43.7)$ & $33(34.7)$ & NS \\
\hline $\mathrm{PCP}^{\mathrm{b}}$ & $31(12.6)$ & $15(15.8)$ & NS \\
\hline Herpes simplex & $30(12.1)$ & $12(12.6)$ & NS \\
\hline Sepsis & $25(10.1)$ & $7(7.4)$ & NS \\
\hline Tuberculosis & $23(9.3)$ & $25(26.3)$ & $\mathrm{S}$ \\
\hline Cryptococcal meningitis & $16(6.5)$ & $5(5.2)$ & NS \\
\hline Toxoplasma encephalitis & $11(4.4)$ & $13(13.7)$ & $\mathrm{S}$ \\
\hline Cryptosporidium parvum in the stools & $7(2.8)$ & $1(1.1)$ & NS \\
\hline $\mathrm{CMV}^{\mathrm{c}}$ disseminated & $5(2.0)$ & $1(1.1)$ & NS \\
\hline Histoplasmosis & $4(1.6)$ & 0 & NS \\
\hline Mycobacterium avium complex & $3(1.2)$ & $1(1.1)$ & NS \\
\hline \multicolumn{4}{|l|}{ Neoplasias } \\
\hline Kaposi's sarcoma & $23(9.3)$ & $3(3.2)$ & NS \\
\hline Lymphoma (non-Hodgkin's) & $4(1.6)$ & $2(2.1)$ & NS \\
\hline Primary lymphoma of the $\mathrm{CNS}^{\mathrm{d}}$ & $3(1.2)$ & $1(1.1)$ & NS \\
\hline
\end{tabular}

${ }^{\mathrm{a}}$ orofaringeal candidiasis occurred in $70 \%$ of the cases; ${ }^{\mathrm{b}}$ Pneumocystis carinii pneumonia; ${ }^{\mathrm{c}}$ cytomegalovirus; ${ }^{\mathrm{d}}$ central nervous system; there is usually more than one diagnose by patient; refusals and not stated removed from Table

patients; $\mathrm{p}=0.0001)$ and toxoplasmosis (11 vs. 13 patients; $\mathrm{p}=0.005)$ was noticed.

Overall, candidiasis was the main clinical diagnosis, followed in different proportions for group 1 and 2 by tuberculosis, Pneumocystis carinii pneumonia, herpes simplex virus infection, central nervous system toxoplasmosis, sepsis and cryptococcosis.

Tuberculosis was one of the most common opportunistic infections diagnosed. If we consider the last admission to hospital and the history of previous treatment for tuberculosis, 91 patients (36.8\%) in group 1 and 33 patients $(34.7 \%)$ in group 2 had tuberculosis.

Paracoccidioidomycosis: Two group 1 patients were diagnosed during hospitalization as having disseminated paracoccidioidomycosis. Both presented pulmonary involvement. An illustrative case is summarized here: he was a 48 year-old, heterosexual promiscuous man, who was admitted to hospital with a history of diffuse abdominal pain, diarrhea and skin lesions which appeared 15 days earlier. He was receiving zidovudine monotherapy for AIDS for the last 12 months. He was skinny, complained of paresthesia of the lower limbs and fatigue, and was unable to walk without support. There was oral thrush. The spleen was palpable $4 \mathrm{~cm}$ below the left costal margin. The skin lesions, affecting the limbs, especially the legs, were in different stages of evolution, with areas of erythema, ulcers and pustules. A biopsy of one of them revealed the presence of Paracoccidioides brasiliensis. A chest $\mathrm{x}$-ray disclosed a diffuse reticule-nodular pattern. The CD4+ count was of 17 cells $/ \mathrm{mm}^{3}$. Amphotericin B (40 mg/day) in the total dose of $3.8 \mathrm{~g}$ was offered. There was a slow but steady improvement in the clinical picture and the patient was discharged from hospital two months after admission in good condition. A chest X-ray taken 3 months later showed disappearance of the micro-nodules. The skin ulcers healed completely leaving brownish scars.

Autopsy: Brain and lungs were the organs most frequently affected during autopsy. The association of diseases was reported for all patients. Tuberculosis, toxoplasma encephalitis, pulmonary pneumocystosis and disseminated CMV disease were the main findings. Primary lymphoma of the central nervous system was described in three individuals; in one, lymphoma was found to be associated to three other diseases, namely: toxoplasma encephalitis, cryptococcal meningitis and HIV encephalopathy. Three individuals presented severe myocarditis and in one, Toxoplasma gondii was identified as the causal agent.

Three other patients had Schistosoma mansoni infection, and in two of them there was a miliary distribution of eggs in many organs (liver, spleen, lungs, intestine, pancreas and testes). They were male of 33 and 53 years of age. Small and incomplete granulomas were observed around the eggs deposited in the tissues. In the liver there was no evidence of Symmers fibrosis; also, no signs of portal hypertension were found. In both, miliary tuberculosis was the main AIDS-related opportunistic disease. Intestinal perforation caused by tuberculosis was described in one patient.

Other associated diseases were: candidiasis (5 cases), disseminated histoplasmosis ( 1 case) and pseudomembranous colitis (1 case), severe HIV leucoencephalopathy (1 case) and bacterial bronchopneumonia (1 case). 


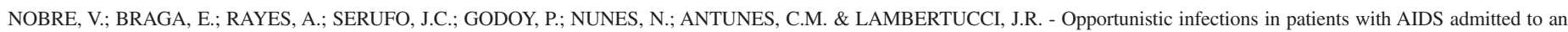
university hospital of the southeast of Brazil. Rev. Inst. Med. trop. S. Paulo, 45(2):69-74, 2003.

There was an agreement between the main clinical diagnoses and the main findings in autopsy in 10 out of 20 cases (50\%). Clinical diagnoses, otherwise, missed a large number of associated diseases.

\section{DISCUSSION}

We retrospectively analyzed the spectrum of opportunistic diseases diagnosed in a large series of AIDS patients in Brazil, before and after the use of highly active antiretroviral therapy. In 20 individuals the diagnoses were then compared with autopsy reports. The overall male-to-female ratio dropped from 5:1 to 2:1 and homosexuality or bisexuality were substituted for heterosexuality as the main risk behavior for HIV infection. These observations follow the tendency observed in the AIDS epidemic in Brazil obtained from the notification of cases to the National Institute of Health ${ }^{3}$. Notwithstanding therapeutic improvements, patients still reach the hospital with severe disruption of the immune system documented by a CD4+ lymphocyte count in both groups under 200 cells $/ \mathrm{mm}^{3}$ in $80 \%$ of patients. Patients of Group 1 spent a shorter time in hospital and that can be explained by the higher mortality rate before 1996 .

A decrease in the number of patients with Kaposi's sarcoma and histoplasmosis in the post HAART group (not reaching statistical significance) has been observed. Yet, the number of cases of tuberculosis and toxoplasmosis increased (respectively, 23 vs. 25 cases; $p=0.0001$ and 11 vs. 13 cases; $p=0.005$ ). In general, the prevalence of tuberculosis was higher than that reported for the United States $(9 \%-18 \%)^{9}$. Tuberculosis in these patients was highly pathogenic, with involvement of at least one extra pulmonary organ in most cases.

An increase in the prevalence of tuberculosis and toxoplasmosis in group 2 has been observed, and this is probably explained by the greater awareness of physicians about both diseases and improvement in the diagnostic methods (such as, CT scan, magnetic resonance imaging, brain biopsy, PCR).

In the last years we have learnt that no group of people or region is protected from the threat of $\operatorname{AIDS}^{2,25}$. But, determining the spectrum of opportunistic infections in a given region requires surveillance systems and diagnostic services that may not be available in many developing countries. For example, opportunistic infections that can be diagnosed with reasonable accuracy by physical examination (e.g., oral candidiasis) or by inexpensive laboratory techniques (e.g., China ink stain of cerebrospinal fluid for Cryptococcus neoformans) may be documented more frequently than opportunistic infections requiring more expensive diagnostic technologies (e.g., Pneumocystis carinii pneumonia, disseminated Mycobacterium avium complex (MAC), cytomegalovirus disease). Biases in diagnosing and reporting opportunistic infections may be especially important among socially disadvantaged groups with limited access to diagnostic and health care services ${ }^{8}$. Finally, differences in clinical definitions may make comparisons between published reports difficult. For these reasons, much less is known about the frequency of different opportunistic infections in the developing world than in industrialized countries ${ }^{6,16,19}$.

The first two patients with paracoccidioidomycosis and AIDS were reported in $1989^{24}$. The largest published review of cases of paracoccidioidomycosis and AIDS involved $27 \mathrm{cases}^{7}$ and except for one patient from Venezuela, all the reported cases of this association occurred in Brazil. Since then, another 15 patients have been reported, being two from Colombia ${ }^{27}$. A wide spectrum of clinical manifestations was seen in the 27 patients described in $1995^{7}$, ranging from indolent infection to rapidly progressive disease. More than one extra pulmonary organ was involved in 19 patients $(70.4 \%)$, with disseminated disease being the most common form of paracoccidioidomycosis. We add here two more cases of paracoccidioidomycosis to the medical literature. Both patients had pulmonary involvement with a micronodular pattern, very much like the miliary pattern seen in disseminated tuberculosis. One had associated skin lesions, and this patient presented a good clinical and radiological response to treatment with amphotericin $\mathrm{B}$. The other patient died in coma of a disease diagnosed clinically as toxoplasma encephalitis; as permission for autopsy was not granted involvement of the brain by Paracoccidioides brasiliensis can not be excluded. The small number of cases of paracoccidioidomycosis in patients with AIDS in Latin America has been attributed to the widespread use of trimethoprimsulfamethoxazole as prophylaxis for Pneumocystis carinii pneumonia. With the spread of AIDS to rural areas of Brazil an increase in the number of cases of associated paracoccidioidomycosis is to be expected.

Three out of 20 patients had severe myocarditis diagnosed during autopsy; in one individual Toxoplasma gondii was identified as the causative agent. Of note, no signs or symptoms of cardiac disease were observed and documented in the medical records of the 3 cases. Myocarditis in HIV patients may play a role in the development of ventricular dysfunction. The incidence of myocarditis at autopsy has been described in one third of all AIDS patients. A specific cause was found in less than $20 \%$ of these patients ${ }^{26}$. Common pathogens in AIDS myocarditis include Toxoplasma gondii, M. tuberculosis, and Cryptococcus neoformans. Other infectious organisms have been reported to include Mycobacterium avium-intracellulare complex, Aspergillus fumigatus, Candida albicans, Histoplasma capsulatum, Coccidioides immitis, cytomegalovirus, herpes simplex and T. cruzi. Recent data suggest that HIV alone can cause myocarditis. Either HIV or its proteins have been found in the heart specimens of patients with AIDS with and without cardiac diseases by culture, by in situ deoxyribonucleic acid hybridization, and by Southern blot tests ${ }^{1,21}$.

Three patients had schistosomiasis mansoni described only after death and two of them presented a miliary distribution of eggs in many organs. Stool examination did not reveal eggs of the worm in one patient. In both, incomplete granulomas were described and they also were found to have concomitant miliary tuberculosis (one, with intestinal perforation attributed to tuberculosis). Data on the behavior of schistosomiasis in the immunosuppressed host are rather scarce. The migration of $S$. mansoni worms to different organs in the human body may explain the finding of a great number of eggs in unusual places. This hypothesis implies that the immune system is important in keeping the adult worms confined to the mesenteric vessels. A chronic miliary form of schistosomiasis in patients with portal hypertension has previously been described but our patients did not have the hepatosplenic form of the disease ${ }^{12}$. It is also interesting to note that egg output decreases sharply in mice experimentally infected with $S$. mansoni and immunosuppressed by drugs or thymectomy; a well-formed granuloma facilitates the migration of eggs in host tissues ${ }^{5}$. Without granuloma formation S. mansoni eggs do not reach the gut lumen and diagnosis of schistosomiasis based on the stool examination is not possible; rectal or liver biopsies and ELISA for circulating antigens would be an alternative to stool examination in this 


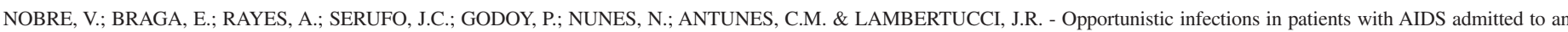
university hospital of the southeast of Brazil. Rev. Inst. Med. trop. S. Paulo, 45(2):69-74, 2003.

context ${ }^{9,11,20}$. It is worth mentioning that in the autopsy of a patient (HIV negative) with Salmonella-S. mansoni association, reported in $1993^{12}$, miliary tuberculosis was also described, as well as $S$. mansoni eggs disseminated in the liver, pancreas, spleen and testes and with incomplete granulomas around the eggs. In the two patients presented here the CD4+ counts in the blood were not too low (126 and 256, respectively) showing that the immunodeficiency was not so severe. Therefore, the association with miliary tuberculosis in our cases may not be a coincidence and a role for this disease (causing more consumption and/or aggravating the disruption of the immune system) in the dissemination of schistosomiasis should be considered.

A comparison between clinical and autopsy data indicates that a significant number of associated diseases remains without a diagnosis during HIV infection. Major clinical efforts should be directed to identifying CMV infection, mycotic diseases (paracoccidioidomycosis should be added to other mycosis affecting AIDS patients in Latin America), schistosomiasis, extrapulmonary tuberculosis and central nervous system diseases, such as, cerebral lymphoma. It is also desirable to know more about the impact of the diseases of developing countries on HIV infection and its evolution ${ }^{9,20}$.

\section{RESUMO}

\section{Infecções oportunistas em pacientes com aids internados em um hospital universitário do sudeste do Brasil}

O espectro das doenças oportunistas em pacientes com aids vem se modificando desde a introdução da terapia antiretroviral altamente eficaz (HAART). O objetivo deste estudo é o de avaliar o perfil das afecções oportunistas em pacientes com aids internados em um hospital universitário do Brasil, comparando os períodos pré e pós-utilização da terapia HAART. Para tanto, revisaram-se os prontuários médicos de 342 pacientes infectados pelo HIV, dividindo-os em dois grupos: grupo 1, composto de 247 pacientes pré-HAART e grupo 2, composto de 95 pacientes pós-HAART. A relação homem-mulher caiu de 5:1 para 2:1. Houve aumento da prevalência da tuberculose e da toxoplasmose, com redução da prevalência do sarcoma de Kaposi, da histoplasmose e da criptococose. Observou-se ainda significativa redução da mortalidade intra-hospitalar ( $42 \%$ vs. $16,9 \% ; p=0,00002)$. A concordância entre o principal diagnóstico clínico e anatomopatológico foi observada em 10 de 20 pacientes necropsiados $(50 \%)$. São relatados dois pacientes com esquistossomose disseminada e dois com paracoccidioidomicose. Em conclusão, excetuando-se a toxoplasmose, houve redução das doenças oportunistas relacionadas à imunossupressão grave nos pacientes pósHAART. Observou-se significativa redução da mortalidade intrahospitalar, possivelmente refletindo a melhora do tratamento dos pacientes HIV-positivos em nosso meio.

\section{REFERENCES}

1. BARBARO, G.; DI LORENZO, G.; GRISORIO, B. \& BARBARINI, G. - Incidence of dilated cardiomyopathy and detection of HIV in myocardial cells of HIV-positive patients. Gruppo italiano per lo studio cardiologico dei pazienti affeti da AIDS. New Engl. J. Med., 339: 1093-1099, 1998.

2. BERKLEY, S. - AIDS in the developing world: an epidemiologic overview. Clin. infect. Dis., 17 (suppl. 2): S329-S326, 1993.
3. BRITO, A.M.; CASTILHO, E.A. \& SZWARCWALD C.L. - Aids e infeccção pelo HIV no Brasil: uma epidemia multifacetada. Rev. Soc. bras. Med. trop., 34: 207-217, 2001 .

4. CENTERS FOR DISEASE CONTROL - 1993 revised classification system for HIV infection and expanded surveillance case definition for AIDS among adolescents and adults. M.M.W.R., 41 (RR-17): 1-19, 1992.

5. DOENHOFF, M.; MUSALLAM, R.; BAIN, J. \& McGREGOR, A. - Studies on the hostparasite relationship in Schistosoma mansoni-infected mice: the immunological dependence of parasite egg excretion. Immunology, 35: 771-778, 1978.

6. DORE, G.J.; KALDOR, J.M.; UNGCHUSAK, K. \& MERTENS, T.E. - Epidemiology of HIV and AIDS in the Asia-Pacific region. Med. J. Aust., 165: 494-498, 1996.

7. GOLDANI, L. \& SUGAR A.M. - Paracoccidioidomycosis and AIDS: an overview. Clin. infect. Dis., 21: 1275-1281, 1995.

8. KAPLAN, J.E.; HU, D.J.; HOLMES, K.K. et al. - Preventing opportunistic infections in human immunodeficiency virus-infected persons: implications for the developing world. Amer. J. trop. Med. Hyg., 55: 1-11, 1996.

9. KARANJA, D.M.S.; HIGHTOWER, A.W.; COLLEY, D.G. et al. - Resistance to reinfection with Schistosoma mansoni in occupationally exposed adults and effect of HIV-1 co-infection on susceptibility to schistosomiasis: a longitudinal study. Lancet, 360: 592-596, 2002.

10. KLATT, E.C.; NICHOLS, L. \& NOGUCHI, T.T. - Evolving trends revealed by autopsies of patients with the acquired immunodeficiency syndrome. 565 autopsies in adults with the acquired immunodeficiency syndrome, Los Angeles, Calif., 1982-1993. Arch. Path. Lab. Med., 118: 884-890, 1994.

11. LAMBERTUCCI, J.R. - S. mansoni: clinical and pathological aspects. In: JORDAN, P.; WEBBE, G. \& STURROCK, R. Human Schistosomiasis. Wallingford, CAB International, 1993. p.160-182.

12. LAMBERTUCCI, J.R. \& NEVES, J. - Associação Salmonella-SchistosomaMycobacterium: relato de um caso. Arq. bras. Med., 67: 53-54, 1993.

13. LAMBERTUCCI, J.R.; RAYES, A.A.M.; SERUFO, J.C. et al. - Schistosomiasis and associated infections. Mem. Inst. Oswaldo Cruz, 93 (suppl. 1): 135-138, 1998.

14. LAMBERTUCCI, J.R.; RAYES, A.A.; NUNES, F.; LANDAZURI-PALACIOS, J.E. \& NOBRE, V. - Fever of undetermined origin in patients with the acquired immunodeficiency syndrome in Brazil: report on 55 cases. Rev. Inst. Med. trop. S. Paulo, 41: 27-32, 1999.

15. LI, Y.; McDONALD, A.M.; DORE, G.J.; KALDOR, J.M. \& NATIONAL HIV SURVEILLANCE COMMITTEE - Improving survival following AIDS in Australia, 1991-1996. AIDS, 14: 2349-2353, 2000.

16. LUCAS, S.B.; HOUNNOU, A.; PEACOCK, C. et al. - The mortality and pathology of HIV infection in a West African city. AIDS, 7: 1569-1579, 1993.

17. MOCROFT, A.; VELLA, S.; BENFIELD, T.L. et al. - Changing patterns of mortality across Europe in patients infected with HIV-1. EuroSIDA Study Group. Lancet, 352: $1725-1730,1998$

18. MORGAdO, M.G.; BARCEllos, C.; PINA, M.F. \& BASTOS, F.I. - Human immunodeficiency virus/acquired immunodeficiency syndrome and tropical diseases: a Brazilian perspective. Mem. Inst. Oswaldo Cruz, 95 (suppl. 1): 145-151, 2000.

19. MURILLO, J. \& CASTRO, K.G. - HIV infection and AIDS in Latin America Epidemiologic features and clinical manifestations. Infect. Dis. Clin. N. Amer., 8: $1-11,1994$

20. MWINZI, P.N.M.; KARANJA, D.M.S.; COLLEY, D.G.; DRAGO, A.S. \& SECOR, W.E - Cellular immune responses of schistosomiasis patients are altered by human immunodeficiency virus type 1 coinfection. J. infect. Dis., 184: 488-496, 2001. 
NOBRE, V.; BRAGA, E.; RAYES, A.; SERUFO, J.C.; GODOY, P.; NUNES, N.; ANTUNES, C.M. \& LAMBERTUCCI, J.R. - Opportunistic infections in patients with AIDS admitted to an university hospital of the southeast of Brazil. Rev. Inst. Med. trop. S. Paulo, 45(2):69-74, 2003.

21. OKOSHI, M.P. \& MONTENEGRO, M.R. - Patologia do coração na AIDS. Estudo de 73 necropsias consecutivas. Arq. bras. Cardiol., 66: 129-133, 1996.

22. PALlELA Jr., F.J.; DELANEY, K.M.; MOORMAN, A.C. et al. - Declining morbidity and mortality among patients with advanced human immunodeficiency virus infection. HIV Outpatient Study Investigators. New Engl. J. Med., 338: 853-860, 1998.

23. PAUL, S.; GILBERT, H.M.; ZIECHECK, W.; JACOBS, J. \& SEPKOWITZ, K.A. - The impact of potent antiretroviral therapy on the characteristics of hospitalized patients with HIV infection. AIDS, 13: 415-418, 1999.

24. PEDRO, R . de J.; AOKI, F.H.; BOCCATO, R.S.B.S. et al. - Paracoccidioidomicose e infecção pelo vírus da imunodeficiência humana. Rev. Inst. Med. trop. S. Paulo; 31: 119-125, 1989.
25. QUINN, T.C. - Global burden of the HIV epidemic. Lancet, 348: 99-106, 1996.

26. RERKPATTANAPIPAT, P.; WONGPRAPARUT, N.; JACOBS, L.E. \& KOTLER, M.N - Cardiac manifestations of acquired immunodeficiency syndrome. Arch. intern. Med., 160: 602-608, 2000.

27. TOBON, A.M.; OROZCO, B.; ESTRADA, S. et al. - Paracoccidioidomycosis and AIDS report of the first two Colombian cases. Rev. Inst. Med. trop. S. Paulo; 40: 377 $381,1998$.

28. VITTINGHOFF, E.; SCHEER, S.; O'MALLEY, P. et al. - Combination antiretroviral therapy and recent declines in AIDS incidence and mortality. J. infect. Dis., 179: 717-720, 1999.

Received: 13 November 2002

Accepted: 26 March 2003 